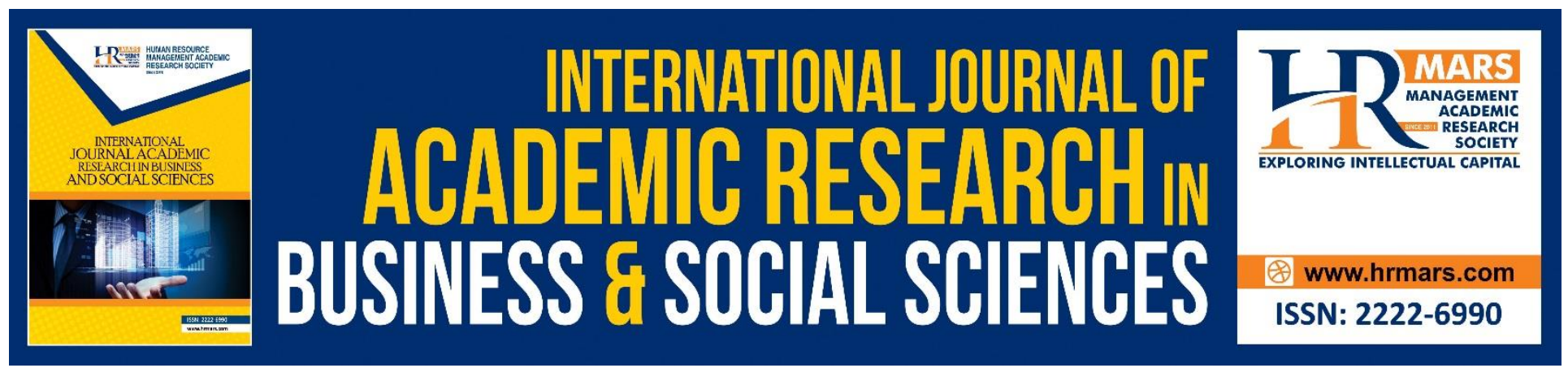

\title{
Attitudes and Motivation towards Malay Language and the Level of Mastery among the Lower Secondary School Students in Pattani, Thailand
}

\section{Zamri Mahamod, Salwa Radwani Jamaludin \& Hadi Hassan}

To Link this Article: http://dx.doi.org/10.6007/IJARBSS/v9-i5/5930

DOI: $10.6007 /$ IJARBSS/v9-i5/5930

Received: 01 March 2019, Revised: 17 March 2019, Accepted: 1 April 2019

Published Online: 29 May 2019

In-Text Citation: (Mahamod, Jamaludin, \& Hassan, 2019)

To Cite this Article: Mahamod, Z., Jamaludin, S. R., \& Hassan, H. (2019). Attitudes and Motivation towards Malay Language and the Level of Mastery among the Lower Secondary School Students in Pattani, Thailand.

International Journal of Academic Research in Business and Social Sciences, 9(5), 604-618.

Copyright: (c) 2019 The Author(s)

Published by Human Resource Management Academic Research Society (www.hrmars.com)

This article is published under the Creative Commons Attribution (CC BY 4.0) license. Anyone may reproduce, distribute, translate and create derivative works of this article (for both commercial and non-commercial purposes), subject to full attribution to the original publication and authors. The full terms of this license may be seen

at: http://creativecommons.org/licences/by/4.0/legalcode

Vol. 9, No. 5, 2019, Pg. 604 - 618

http://hrmars.com/index.php/pages/detail/IJARBSS

JOURNAL HOMEPAGE

Full Terms \& Conditions of access and use can be found at http://hrmars.com/index.php/pages/detail/publication-ethics 


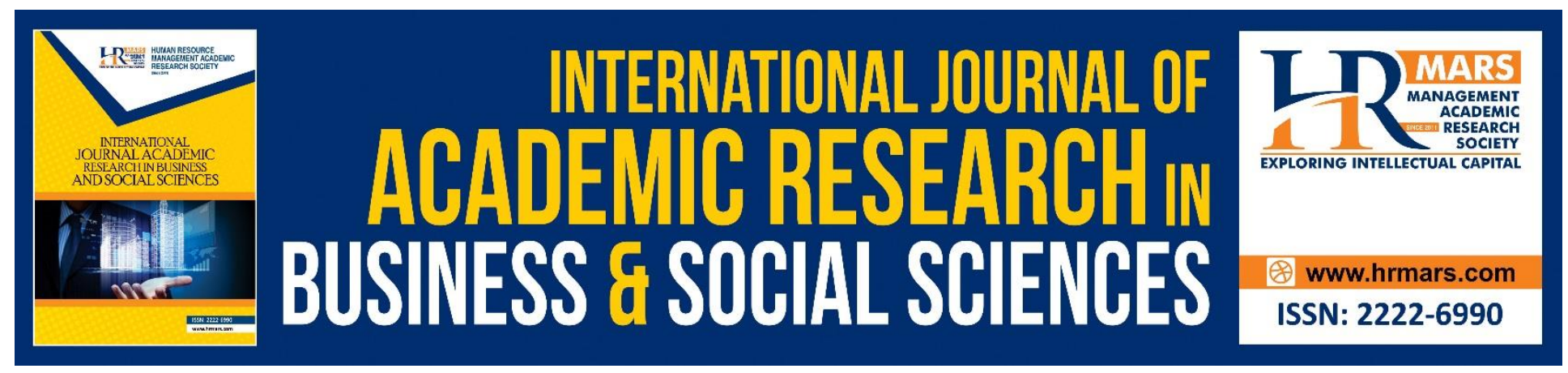

\title{
Attitudes and Motivation towards Malay Language and the Level of Mastery among the Lower Secondary School Students in Pattani, Thailand
}

\author{
Zamri Mahamod, Salwa Radwani Jamaludin \& Hadi Hassan \\ Faculty of Education, Universiti Kebangsaan Malaysia, 43600 UKM Bangi, \\ Selangor Darul Ehsan, Malaysia
}

\begin{abstract}
This study was conducted to obtain information on attitude towards Malay language and its level of mastery among lower secondary school students in Pattani, Thailand. This study was also conducted to examine the level of mastery of Malay Language among those who attended the Malay Language course. The survey research was conducted using quantitative method utilizing questionnaire instrument which was administered on 100 Form 3 students in two randomly selected schools in Pattani, Thailand. The data obtained were analyzed through descriptive and inferential statistics which is t-test and correlation test. The study was conducted based on socio-education model by Gardner. The results showed that the attitude of students in learning Malay was at moderately high level $(\min =3.55, \mathrm{sd}=1.00)$. The results of the study based on the motivation of students in studying Malay Language showed the same result which is medium high (mean $=3.46, s d=0.98$ ). The implication of the study showed that the motivation of the southern Malay student of Thailand will increase if the mastery and skills of Malay language increase in learning.
\end{abstract}

Keywords: Attitudes, Malay Language Education, Teaching and Learning, Secondary School

\section{Introduction}

The education system in Southern Thailand differs from the education system in other parts of Thailand. Worawit (1990) explains that education systems in the four provinces of Southern Thailand, which are Pattani, Yala, Narathiwat, and Satun are categorized as the Second Education District by the Ministry of Education of Thailand. The education system in this area differs from the education system in other educational districts due to religion, language and cultural differences. Ismail (2007) and Worawit (1999) says that the Malays in Thai still use Malay Language and practice Malay customs and culture especially for those who live in the border of Southern Thai. 
The change occurred in the education system in Southern Thailand (Pattani) mainly in terms of offering Malay Language course as one of the foreign language courses. In the early stages, Malay language courses are offered only at the university level, but now the course is offered in secondary school as a foreign language course. Malay language is not a mandatory subject, but only as an elective subject in government and religious schools.

The education system in Pattani can be divided into three types of government schools, partial government schools, and private schools. Each school offers Malay language subjects as one of the foreign languages that must be attended by the students in the lower secondary level which is from form one to form three. At the upper secondary level, students will be given the option of selecting other foreign languages such as Japanese, Filipino, and English. In such cases, the subjects of Malay Language are only offered at the lower level and not continued to the upper secondary levels. This situation may be the cause of the students not able to master Malay language and not interested in learning the language (Kartini, Zulkifley, Pareeda \& Suhaila 2015).

Teachers of Malay language teaching and learning are mostly graduates of local universities who pursue Malay Language studies at Prince of Songkhla University, Thailand. Teachers often use Pattani dialect in the delivery of Malay Language teaching because they think students are more likely to understand the contents of the teaching they want to convey. The Malay syllabus for high school in Pattani was significantly different from the Malay syllabus in Malaysia. Such a situation has led the researcher to conduct a thorough study of the oral level of Malay Language proficiency as well as the problems faced by the form three students in the process of Malay Language teaching and learning.

\section{Problem Statement}

Mastery of Malay language among students is still weak, and there are Malay Thai students who are unable to speak Malay. This situation can be seen happened as a result of the long-established assimilation policy by the Thai government. Assimilation policy based on the coercive power of the government is demanded that all ethnic groups in Thailand accept and practice Thai culture which includes language. Hence, the offering of Malay language subject at the secondary school is regarded as a foreign language for students, especially among minorities, namely Malay Thai. The dialect practiced which is Pattani dialect is a Malay language that has never experienced any language planning unlike the Malay language in Malaysia that has always undergone language planning that changes from time to time (Syafina 2018). Even so, the younger generation has not known or exposed to the Pattani dialect except for the elderly. The younger generation is more vulnerable to Thai culture and has regarded Thai as the main language (Chakapia, 2008).

At the school level, Malay language subject are only offered at the lower secondary level. Students learn Malay as one of the essential subjects and are considered less important. Zamri (2014) stated that there are some factors such as the problem of the Malay language teachers' quality, the lack of textbooks and appropriate reading materials, the negative attitude of Malay students towards Malay language subject, no grammar books, unsteady language system, as well as inappropriate language teaching and learning methods. Zamri (2016) states that the linguistic factor in the Malay language 
INTERNATIONAL JOURNAL OF ACADEMIC RESEARCH IN BUSINESS AND SOCIAL SCIENCES

Vol. 9, No. 5, May, 2019, E-ISSN: 2222-6990 (C) 2019 HRMARS

itself serves to cause disruption or influence the development of the standard Malay language and is a dominant factor in determining the occurrence of such matters.

\section{Research Aims}

This study is aimed to identify students' attitude toward Malay language and to study the level of Malay language proficiency among students. The study that identify students' attitude in learning Malay language is very important in order to see the extent of Malay language usage abroad. Additionally, the offering of Malay language subjects in the syllabus in Southern Thailand is still at a new level and requires a deep understanding of the importance of the language being offered. This study was conducted to see if there were differences between attitude, motivation, achievement, and level of mastery of Malay language in two different types of school.

\section{Research Questions}

The study was conducted to answer the following questions:

1. What is the attitude, motivation, level of mastery, and achievement of lower secondary school students in Malay language in Pattani?

2. Is there a significant difference in attitude and motivation towards learning Malay language between government school and private school students?

3. Is there a relationship between attitude and motivation with the level of language mastery of student in learning Malay language?

4. Is there a relationship between attitude and motivation with achievement in the Malay language subject?

\section{Research Hypotheses}

This hypothesis aims to answer the questions as follows:

Ho1 -There is no significant difference in attitudes towards Malay language learning among the government and private school students.

Ho2 -There is no significant difference in the motivation for learning Malay language among the government and private school students.

Ho3 -There is no significant relationship between attitudes with the level of language mastery of the students in learning Malay.

Ho4 -There is no significant relationship between motivation and the level of language mastery of the students in learning Malay.

Ho5 -There is no significant relationship between attitude and students' achievement in Malay language subject.

Ho6 -There is no significant relationship between motivation and students' achievement in Malay language subject.

\section{Importance of the Study}

This study is important to identify the objectives of Malay language subject offered at the lower secondary level. A few rationales that can be taken into account to ensure that the subject is not offered in vain and has their significance. In addition, this study indirectly identifies the problems 
INTERNATIONAL JOURNAL OF ACADEMIC RESEARCH IN BUSINESS AND SOCIAL SCIENCES

Vol. 9, No. 5, May, 2019, E-ISSN: 2222-6990 @ 2019 HRMARS

faced by the students during the teaching and learning process and can help teachers to take a new approach in the T\&L process to attract students to learn Malay language more deeply.

This study is important to ensure that the students appreciate the learning duration of the subject especially among Malay Thai students as Malay Language is their native language. This study also has the potential to see the extent of Malay language position among high school students. This is because they belong to the modern-day generations who have been exposed to the rapid tide of modernization. The study is conducted at two different types schools is carried out to see the difference in terms of students' achievement in the Malay language subject. This study will be conducted in detail to see if there is a difference in terms of the level of Malay language proficiency in two different types of school.

In a nutshell, this study is conducted in order for the parties to take an effective approach in developing Malay language more thoroughly. This study is also expected to attract local stakeholders in Malaysia to further strengthen cooperation with the school in this region to further expand Malay Language education. Indeed, the school authorities in Dechapattanayanukul School are always practicing openness in the field of education in order to improve school performance to a universal level in line with the level of government school. However, the researcher will also examine the teaching methods implemented in the private schools and see if there is a correlation between the methods implemented with the students' attitude towards Malay language.

\section{Literature Review}

Malay Pattani Language was once a language of knowledge and successfully placed Pattani as a center of civilization of Malay Islamic literature through the production of religious books by scholars. The book is widely used until it reaches the Middle East and North Africa. Nevertheless, the splendor of Malay language in Pattani has faded since Pattani became part of Thailand. The Thai government has banned the use of Malay language at various levels including schools and offices. The act had a tremendous impact on the position of Malay language. Ismail (2007) and Worawit (1999) states Pattani residents are required to regard themselves as Thai people and Thai descent, although they are actually Malay people and Muslim.

Ahmad Fathy (2001) states the medium that can be used to be proficient in Malay Pattani is now only in daily interaction, religious teaching, and sermon (khutbah) presentation. He also noted that Malay language was no longer used in official government affairs, signage, and mass media. Norizah (2005) conducted a sociolinguistic study on the attitude towards Malay language and its use among university students in Southern Thailand. The finding shows that students have positive attitude towards Malay language. Motivation of respondents in learning Malay language is integrative, instrumental, and based on identity and loyalty to the mother tongue. The use of Malay language only occurs among Muslim respondents. The Malay language used mostly in the form of mixed code between Malay and Thai language. His study shows that respondents have a positive attitude about Malay language but their use is limited. 
Various studies have been carried out in relation to the Pattani Muslim Malay community and mostly focused only on the history of past glory and have a connection to the language and religion. Paitoon (2005), in his study found that nearly 75 percent of Pattani's Muslim population, who obey Malay customs, and speaking in Malay dialect of Pattani. Study by Ab. Razak and Muhammad Saiful Haq (2011) on the level of mastery of Malay Language among students at the Islamic Santitham Foundation School (ISFS) indicate that the level of reading comprehension in Malay among students is very weak and that affects their achievement which is deteriorating. The study also identifies the root cause of the problem is that the approaches, methods, and techniques used by the teachers in teaching is not systematic.

Malay Pattani language has long existed and developed over thousands of years before Pattani was placed under the rule of Thailand (Ismail 2007). The study on the level of achievement of the Ayuthia and Pattani Malays minority in Thailand in the domain of family, language, culture, education, occupation, social, and political shows that Pattani Malay minority is far better than Ayuthia in all domains (Muhammad Rozi \& Mohd Sazili 2013). The study of Kartini et al. (2015) found that teachers teaching Malay language were influenced by the Pattani Malay dialect especially in terms of pronunciation of the words. The study focuses on the influence in terms of the change of the pronunciation of the word which is the change in the phonetic aspect that occurred due to the local dialect.

\section{Methodology \\ Research Design}

This study was carried out using quantitative methods in the form of survey. Data collection through surveys is used in quantitative methods. The researcher used quantitative method with data collection through questionnaire instrument. The questionnaire was adapted and modified from the questionnaire used by Jerie and Zamri (2011) in the study on the attitude and motivation of students who study Malay language as the second language. The data obtained will be analyzed using the Statistical Package for The Social Sciences (SPSS) version 2.0. The data will be analyzed using two types of statistics, which is inferential statistics and descriptive statistics. Descriptive analysis is a procedure used to measure and describe quantitative data (Mohd Majid 2005). Descriptive statistics used can describe or summarize information on data obtained from the study (Azizi \& Shahrin 2007).

\section{Population, Location, and Sample}

Respondents in this study consist of 100 Form 3 students which are selected according to the same level. The selection of students as respondents of the study was conducted in two different types of school but still at the same level to avoid the occurrence of error in terms of data collection. The selection of this sample is done to represent the entire student who attended Malay language class from form one to form three. The study sample consists of the students who are at the top class of the 13 classes to get more relevant information for this study. The study was conducted at the Dechappatanayanukul School and Bamrung Islamic Middle School in Pattani, Thailand. The selection of the two schools is appropriate with the study as they are in the same district but different in the 
INTERNATIONAL JOURNAL OF ACADEMIC RESEARCH IN BUSINESS AND SOCIAL SCIENCES

Vol. 9, No. 5, May, 2019, E-ISSN: 2222-6990 @ 2019 HRMARS

form of types of school, syllabus and students. The difference in the type of school in this study can have a slight impact on this assessment.

\section{Research Instrument}

The instrument which is the questionnaires used in this study consists of four parts as shown in Table 1.

Table 1: Item Distribution of the Questionnaire Form

\begin{tabular}{lc}
\hline \multicolumn{1}{c}{ Section } & Number of Questions Items \\
\hline Section A - Respondent's Personal Information & 4 \\
Section B - Language and Education Information & 3 \\
Section C - Students' Attitude towards Malay Language & 13 \\
Section D - Motivation of Students in Learning Malay Language & 13 \\
\hline \multicolumn{1}{c}{ Total in All Sections } & 33 \\
\hline
\end{tabular}

\section{Research Findings}

Descriptive analysis is used to obtain frequency, percentage, and mean values to answer question one and three. Research questions two, three, and four are answered using inferential analysis such as t-test and Pearson Correlation test to test the hypothesis based on the research questions built.

Table 2: Profile and achievement of study sample

\begin{tabular}{llcc}
\hline \multicolumn{1}{c}{ Item } & \multicolumn{1}{c}{ Category } & Frequency & Percentage \\
\hline Types of school & Government School & 50 & $50.0 \%$ \\
Gender & Public School & 50 & $50.0 \%$ \\
\multirow{3}{*}{ Races } & Male & 24 & $24.0 \%$ \\
Territory of Origin & Female & 76 & $76.0 \%$ \\
& Thai Malay & 56 & $56.0 \%$ \\
& Thai & 44 & $44.0 \%$ \\
& Pattani & 82 & $82.0 \%$ \\
& Narathiwat & 7 & $7.0 \%$ \\
Spoken Language & Satun & 1 & $1.0 \%$ \\
Final Year Examination Results & Yala & 5 & $5.0 \%$ \\
(Malay Language): & Others & 5 & $5.0 \%$ \\
& Malay Language (Pattani) & 46 & $46.0 \%$ \\
& Thai Language & 54 & $54.0 \%$ \\
& B & 69 & $69.0 \%$ \\
& C & 21 & $21.0 \%$ \\
& D & 5 & $5.0 \%$ \\
& E & 4 & $4.0 \%$ \\
\hline
\end{tabular}

Although the results of the Malay language subject examination were high, the findings of language proficiency showed that students' skills in speech, reading, writing, and listening were low. 
INTERNATIONAL JOURNAL OF ACADEMIC RESEARCH IN BUSINESS AND SOCIAL SCIENCES Vol. 9, No. 5, May, 2019, E-ISSN: 2222-6990 @ 2019 HRMARS

Table 3: Level of Malay language proficiency by aspect

\begin{tabular}{lcc}
\hline Level of Malay Language Proficiency & Frequency & Percentage \\
\hline Speaking: & 30 & $30.0 \%$ \\
- Fluent & 37 & $37.0 \%$ \\
- Moderate & 13 & $13.0 \%$ \\
- Less Fluent & 20 & $20.0 \%$ \\
- Do not know & & \\
Reading: & 38 & $38.0 \%$ \\
- Fluent & 35 & $35.0 \%$ \\
- Moderate & 20 & $20.0 \%$ \\
- Less Fluent & 7 & $7.0 \%$ \\
- Do not know & & \\
Listening & 30 & $30.0 \%$ \\
- Fluent & 40 & $40.0 \%$ \\
- Moderate & 11 & $11.0 \%$ \\
- Less Fluent & 19 & $19.0 \%$ \\
- Do not know & & \\
Writing: & 36 & $36.0 \%$ \\
- Fluent & 29 & $29.0 \%$ \\
- Moderate & 24 & $24.0 \%$ \\
- Less Fluent & 11 & $11.0 \%$ \\
- Do not know & & \\
\hline
\end{tabular}

Attitudes of Lower Secondary School Students towards Malay Language Learning

Table 4 shows the mean and standard deviation of the two main elements in the study, namely students' attitude and motivation in learning Malay language. The overall mean of students' attitude in learning Malay language is at medium high level (mean $=3.55, \mathrm{sd}=1.00$ ). 
INTERNATIONAL JOURNAL OF ACADEMIC RESEARCH IN BUSINESS AND SOCIAL SCIENCES Vol. 9, No. 5, May, 2019, E-ISSN: 2222-6990 @ 2019 HRMARS

Table 4: Students' attitude in learning Malay language

\begin{tabular}{cccc}
\hline Element & Mean & Standard Deviation & Mean Interpretation \\
\hline Attitude & 3.55 & 1.00 & Moderately high \\
\hline
\end{tabular}

Table 5 shows the mean and standard deviation of the attitude of lower secondary school students in Malay language learning for each item. A total of 13 items were submitted in the questionnaire to identify students' attitude towards Malay language learning. The findings showed that the lower secondary school students had moderately high attitudes in learning Malay language. The details of this finding are based on the highest mean value of this item is 'I am happy to be acquainted with Thai Malays' (mean $=4.01$, sd $=1.11$ ) whereas the lowest mean value is 'I always complete Malay language homework' (mean $=3.02$, $s d=1.38$ ). Although the mean value is such, but each item still shows a moderate mean value.

Table 5: Attitudes of lower secondary school students in learning Malay language

\begin{tabular}{|c|c|c|c|c|}
\hline No. & Item & Mean & $\begin{array}{l}\text { Standard } \\
\text { Deviation }\end{array}$ & $\begin{array}{c}\text { Mean } \\
\text { Interpretation }\end{array}$ \\
\hline 1 & I like Thai Malay people & 3.97 & 1.02 & Moderate \\
\hline 2 & I am very happy to know Thai Malay people. & 4.01 & 1.11 & High \\
\hline 3 & Thai Malays love to associate with others. & 3.78 & 1.15 & high \\
\hline 4 & Thai Malays can be trusted. & 3.83 & 1.10 & $\begin{array}{l}\text { Moderately } \\
\text { High }\end{array}$ \\
\hline 5 & Thai Malays are kind. & 3.81 & 1.11 & $\begin{array}{l}\text { Moderately } \\
\text { High }\end{array}$ \\
\hline 6 & I can speak Malay if I mix with Thai Malays. & 3.22 & 1.48 & $\begin{array}{l}\text { Moderately } \\
\text { High }\end{array}$ \\
\hline 7 & $\begin{array}{l}\text { I want to know deeply about the Thai } \\
\text { Malays. }\end{array}$ & 3.71 & 1.26 & $\begin{array}{l}\text { Moderately } \\
\text { High }\end{array}$ \\
\hline 8 & I concentrate on Malay language classes. & 3.59 & 1.14 & $\begin{array}{l}\text { Moderately } \\
\text { High }\end{array}$ \\
\hline 9 & $\begin{array}{l}\text { always complete Malay language } \\
\text { homework. }\end{array}$ & 3.02 & 1.54 & $\begin{array}{l}\text { Moderately } \\
\text { High }\end{array}$ \\
\hline 10 & I earnestly learn Malay language. & 3.44 & 1.38 & $\begin{array}{l}\text { Moderately } \\
\text { High }\end{array}$ \\
\hline 11 & $\begin{array}{l}\text { I love reading Malay language reading } \\
\text { materials. }\end{array}$ & 3.21 & 1.44 & $\begin{array}{l}\text { Moderately } \\
\text { High }\end{array}$ \\
\hline 12 & I am interested in learning Malay language. & 3.33 & 1.45 & $\begin{array}{l}\text { Moderately } \\
\text { High }\end{array}$ \\
\hline 13 & I was attracted to Malay language subject. & 3.28 & 1.27 & $\begin{array}{l}\text { Moderately } \\
\text { High }\end{array}$ \\
\hline
\end{tabular}


INTERNATIONAL JOURNAL OF ACADEMIC RESEARCH IN BUSINESS AND SOCIAL SCIENCES Vol. 9, No. 5, May, 2019, E-ISSN: 2222-6990 @ 2019 HRMARS

\section{Motivation of Lower Secondary School Students in Learning Malay Language}

Table 6 shows the mean and standard deviation of students' motivation in learning Malay language. The overall mean of students' motivation is moderately high ( mean $=3.46, \mathrm{sd}=0.98$ ).

Table 6: Motivation of lower secondary school students in learning Malay language

\begin{tabular}{cccc}
\hline Element & Mean & Standard Deviation & Mean Interpretation \\
\hline Motivation & 3.45 & 0.98 & Moderately high \\
\hline
\end{tabular}

\section{Level of Motivation of Lower Secondary School Students in Learning Malay Language}

Table 7 shows the mean and standard deviation of the motivation of lower secondary school stud9ents in learning Malay language for each item. A total of 13 items were submitted in the questionnaire to identify students' motivation in learning Malay language. The finding shows that high school students have moderate level of motivation in learning Malay language. The items with the highest mean values among all the items is 'Mastering Malay language allows me to get good test results' (mean $=3.91, \mathrm{sd}=1.06$ ) whereas the item with the lowest mean value is 'I plan to do business in Malaysia' (mean $=2.96, \mathrm{sd}=1.36$ ). Although the mean value is such, but each item still shows a moderate mean value. 
INTERNATIONAL JOURNAL OF ACADEMIC RESEARCH IN BUSINESS AND SOCIAL SCIENCES Vol. 9, No. 5, May, 2019, E-ISSN: 2222-6990 @ 2019 HRMARS

Table 7: Motivation level of high school students in learning Malay language

\begin{tabular}{|c|c|c|c|c|}
\hline No. & Item & Mean & $\begin{array}{l}\text { Standar } \\
\quad \mathrm{d} \\
\text { Deviatio } \\
\mathrm{n}\end{array}$ & $\begin{array}{c}\text { Mean } \\
\text { Interpretation }\end{array}$ \\
\hline 1 & $\begin{array}{l}\text { Malay language makes it easy for me to } \\
\text { connect with Thai Muslims. }\end{array}$ & 3.61 & 1.31 & $\begin{array}{l}\text { Moderately } \\
\text { High }\end{array}$ \\
\hline 2 & $\begin{array}{l}\text { Malay Language is important for me to } \\
\text { communicate in my village/town of my home. }\end{array}$ & 3.51 & 1.23 & $\begin{array}{l}\text { Moderately } \\
\text { High }\end{array}$ \\
\hline 3 & $\begin{array}{l}\text { Malay Language is important to me as most of } \\
\text { my friends like to speak in Malay language } \\
\text { with Pattani dialect. }\end{array}$ & 3.58 & 1.16 & $\begin{array}{l}\text { Moderately } \\
\text { High }\end{array}$ \\
\hline 4 & $\begin{array}{l}\text { Malay Language is important to enable me to } \\
\text { communicate with my friends and relatives } \\
\text { living in Malaysia. }\end{array}$ & 3.39 & 1.37 & $\begin{array}{l}\text { Moderately } \\
\text { High }\end{array}$ \\
\hline 5 & I plan to work in Malaysia. & 3.01 & 1.35 & $\begin{array}{l}\text { Moderately } \\
\text { High }\end{array}$ \\
\hline 6 & I plan to pursue my studies in Malaysia. & 3.24 & 1.42 & $\begin{array}{l}\text { Moderately } \\
\text { High }\end{array}$ \\
\hline 7 & I plan to do business in Malaysia. & 2.96 & 1.36 & $\begin{array}{l}\text { Moderately } \\
\text { High }\end{array}$ \\
\hline 8 & $\begin{array}{l}\text { By taking the Malay language course, it is } \\
\text { easier for me to get a job. }\end{array}$ & 3.19 & 1.28 & $\begin{array}{l}\text { Moderately } \\
\text { High }\end{array}$ \\
\hline 9 & $\begin{array}{l}\text { Knowledge of Malay Language makes it easier } \\
\text { for me to get information and entertainment } \\
\text { from the media (radio, television, newspaper) } \\
\text { from Malaysia. }\end{array}$ & 3.61 & 1.15 & $\begin{array}{l}\text { Moderately } \\
\text { High }\end{array}$ \\
\hline 10 & $\begin{array}{l}\text { My parents encouraged me to learn Malay } \\
\text { language. }\end{array}$ & 3.62 & 1.18 & $\begin{array}{l}\text { Moderately } \\
\text { High }\end{array}$ \\
\hline 11 & $\begin{array}{l}\text { I have advantages if I am proficient in Malay } \\
\text { Language. }\end{array}$ & 3.59 & 1.22 & $\begin{array}{l}\text { Moderately } \\
\text { High }\end{array}$ \\
\hline 12 & Malay Language is a mandatory subject. & 3.81 & 1.18 & $\begin{array}{l}\text { Moderately } \\
\text { High }\end{array}$ \\
\hline 13 & $\begin{array}{l}\text { Mastering Malay Language allows me to get } \\
\text { good test results. }\end{array}$ & 3.91 & 1.06 & $\begin{array}{l}\text { Moderately } \\
\text { High }\end{array}$ \\
\hline
\end{tabular}

Relationship between Attitude and Motivation with the Malay Language Proficiency Level of the Students

The result of the analysis using the Pearson correlation shows that three independent variables have a strong negative correlation namely the attitude with proficiency level $(r=-0.762)$ and motivation 
INTERNATIONAL JOURNAL OF ACADEMIC RESEARCH IN BUSINESS AND SOCIAL SCIENCES Vol. 9, No. 5, May, 2019, E-ISSN: 2222-6990 @ 2019 HRMARS

with proficiency level ( $r=-0.795)$. The relationship between independent variables of attitude and motivation showed a strong positive relationship $(r=0.832)$. The three correlations are significant at $\mathrm{p}<0.05$. Therefore, $\mathrm{Ho} 2$ hypothesis indicates that there is no significant relationship between the three variables is rejected. This result shows that positive attitudes and motivations affect the level of students' mastery towards the betterment.

Table 8: Correlation test between attitude, motivation, and level of Malay Language proficiency

\begin{tabular}{ccccc}
\hline \multicolumn{2}{c}{ Relationship } & Pearson Correlation & Sig. & Interpretation \\
\hline Attitude & Proficiency Level & $-0.762^{*}$ & 0.000 & Strong \\
Motivation Proficiency Level & $-0.795^{*}$ & 0.000 & Strong \\
Attitude $\quad$ Motivation & $0.832^{*}$ & 0.000 & Strong \\
\hline
\end{tabular}

Level of Significance at 0.05

Relationship between Attitude and Motivation with the Achievement in Malay Language Subject The result of the analysis using the Pearson $r$ correlation shows that two dependent variables have a moderate negative relationship which are attitudes with achievement level $(r=-0.306)$ and motivation with achievement level $(r=-0.339)$. The results of the correlation test showed that the three variables were at a significant level of $p<0.05$. Therefore, the Ho3 hypothesis that there is no significant relationship between the three elements involved is rejected. This proves that the attitude and motivation of students in learning Malay language influence the level of Malay Language achievement.

Table 9: Correlation test between attitude, motivation, and achievement level in Malay language subject

\begin{tabular}{ccccc}
\hline \multicolumn{2}{c}{ Relationship } & Pearson Correlation & Sig. & Interpretation \\
\hline Attitude & Achievement Level & $-0.306^{*}$ & 0.002 & Moderate \\
Motivation & Achievement Level & $-0.339^{*}$ & 0.001 & Moderate \\
\hline
\end{tabular}

Level of Significant at 0.05

\section{Discussion}

The findings of the study showed that students' attitude towards learning Malay language is at moderately high level which represent the overall respondents. If viewed from the different type school, attitudes of private schools students are higher than government school. Student motivation in learning Malay also shows the same level of attitude that is moderately high. As a whole, students in Southern Thailand still have positive attitudes and motivations in learning Malay language. This finding supports the study of Jerie and Zamri (2011) which shows that Iban primary school students have a positive attitude and motivation when learning Malay language as their second language. The findings show that students still have an interest in learning Malay language but the interest depends on the learning period for Malay language subject. The findings also support the study of Nur Syafina (2018) and Norizah (2005) which was conducted among students in Southern Thailand. Her study 
INTERNATIONAL JOURNAL OF ACADEMIC RESEARCH IN BUSINESS AND SOCIAL SCIENCES Vol. 9, No. 5, May, 2019, E-ISSN: 2222-6990 @ 2019 HRMARS

found that students were positive towards Malay language; however, the use of Malay language among students was limited. The findings show that students were not adequately exposed to Malay language and furthermore, they were unable to develop their existing knowledge to the appropriate extent due to the environmental constraints.

The finding in terms of relationship between attitudes, motivation, and level of mastery also show strong relationship. This shows that students with positive attitudes and motivations will have good impact on their level of Malay language proficiency. However, if it is on the contrary, the students' proficiency is at a low level. This study supports the study findings of Mohamad Yazid (2017) which states that the level of Malay language proficiency in Kensiu is very weak and they are also difficult to understand the pronunciation by the teachers and still do not recognize the letters. The situation was due to the teaching style of the teachers which used local language as the medium of instruction in learning Malay language. This factor affects the level of mastery of students in learning Malay language.

The study of Nur Syafina (2018) found that among the identified factors that influenced their achievement are the mother tongue influence, the attitude of the students and their parents, the identity of the individual, the cultural differences, the economy, the learning and teaching style, and the teacher-student relationship. This study also supports the findings of Ab. Razak and Muhammad Saiful Haq (2011) which indicates the level of mastery of Malay language among Thai students is weak. This is because the language policy and education policies practiced by the Thai government do not provide space for Malay language development. The researcher concluded that the results of the study have supported the findings of the study conducted by Kamiliah Ayu (2015) and Kartini et al. (2015) involving the language and education policies practiced by schools in Southern Thailand.

The findings of the study on the relationship between attitudes, motivation, and achievement levels showed moderate correlation. The researcher found that the achievement level of students in Malay language subjects was at an unsatisfying level. As a whole, the level of student achievement in Malay language subject depends only on achievement solely and the students are not very concerned about the learning. This is because the offer of Malay language subject is a mandatory subject to be taken and has no other importance.

\section{Conclusion}

As a conclusion, the researcher concluded that the attitude toward Malay language and its level of mastery among high school students in Pattani district, Thailand is still moderate. This study proves that there is a slight difference in education in two different types of schools. However, the findings still show the same results in terms of attitudes, motivations, achievement levels, and the level of mastery of students. Therefore, the effectiveness of Malay language teaching affects the attitude of students in learning the language. The efforts of the school administration in offering Malay language subject should be praised because the attitude of openness is able to expand Malay language to a more global level. 
INTERNATIONAL JOURNAL OF ACADEMIC RESEARCH IN BUSINESS AND SOCIAL SCIENCES Vol. 9, No. 5, May, 2019, E-ISSN: 2222-6990 @ 2019 HRMARS

In addition, the findings contributed in terms of attitude and motivation and teaching pedagogy. In terms of attitude and motivation, the attitude and motivation factors did not affect the Malay students in southern Thailand to learn Malay language. Their attitudes and motivations are largely influenced by the basic Thai language of the Thai language which emphasizes Thai primarily though the majority of the population in southern Thailand are Malays. Thai students in southern Thailand are forced to learn Thai if they want to continue their studies and work in Thailand.

In terms of teaching pedagogy, the level of mastery of the students can be enhanced if the teacher takes the appropriate approach especially in the teaching of Malay language. The approaches, methods, and techniques used by teachers need to be streamlined to be more systematic in attracting students' interest and motivation to continue to learn Malay language. Although the offering of Malay subjects is limited, the Thai education policy has been blocking the development of the language, but the parties involved mainly the Foreign Language Department and teaching teachers can change the situation in the teaching and learning process in the classroom. Teachers need to be exposed in Malay language teaching even though Malay is a minority language in Thailand.

\section{References}

Ab. Razak, A. K. \& Muhammad Saiful Haq, H. (2011). Level of Mastery of Malay Language Students at Islamic Santitham Foundation School. Journal of Malay Studies, 22: 18-31. (In Malaysia).

Azizi, Y. \& Shahrin, H. (2007). Master the Research in Education. Kuala Lumpur, Malaysia: PTS Profesional Publishing Press.

Fathiyah Chakapia, O. C. (2008). Malay Language Teaching Practice in Southern Thai Religious Schools: Case Study at Phatanasad Muslim Schools. Master Thesis. Faculty of Education, Universiti Malaya, Kuala Lumpur, Malaysia.

Ismail, S. (2007). Malay Language in Thai Countries. Kuala Lumpur, Malaysia: Dewan Bahasa dan Pustaka Press.

Jerie, P. L. \& Zamri, M. (2011). Attitude and Motivation of Iban Students in Learning Malay Language as a Second Language. Malay Language Education Journal, 1 (1): 13-25. (In Malaysia).

Kamiliah Ayu, A. G. (2015). Malay Learning Strategies among Non-Malay Students. Project Paper of Master Education. Faculty of Education, Universiti Kebangsaan Malaysia, Malaysia.

Kartini, W., Zulkifley, H., Pareeda, H. \& Suhaila, B. (2015). Standard Malay language teaching among border communities: Study of Influence of Pattani Dialect in Southern Thailand. Geografia Online, Malaysian Journal of Society and Space, 11: 36-34. (In Malaysia).

Yazid, M. (2017). Frequency of Using Malay Language Learning Strategies among Excellent Chinese Ethnic Students. Malay Language Education Journal, 7 (1): 85-92. (In Malaysia).

Mohd Majid, K. (2005). Educational Assessment Methods. 7th Edition. Kuala Lumpur, Malaysia: Dewan Bahasa dan Pustaka Press.

Rozi, M. \& Mohd Sazili, S. (2013). Malay Minority Ayuthia and Pattani in Domain Family, Language, Culture, Education, Works, Social and Politics. Journal of Malay Studies, 6 (1). (In Malaysia).

Norizah, A. (2005). Attitudes towards Malay Language and Its Uses among Students of Southern Thailand University. Doctoral Thesis. Faculty of Language and Linguistics, Universiti Malaya, Kuala Lumpur, Malaysia. 
Syafina, M. S. (2018). Language Learning Strategy among Undergraduates Students in Malay Language Program in Prince of Songkhla University, Pattani Based on Gender, Years of Studies and Achievements Leve. Malay Language Education Journal, 8 (2): 1-12. (In Malaysia)

Paitoon, M. C. (2005). Transmorfofonologisasi Suprafiks: Dialek Patani Merentas Zaman. Language Journal, 5 (1): 51-67. (In Malaysia)

Worawit, B. (1990). The Influence of Thai Language om Pattani Dialect. Master Thesis. Academy of Malay Studies, Universiti Malaya, Kuala Lumpur, Malaysia.

Worawit, B. (1999). Government Policy and Its Impact on Malay Language in Thai Countries. Doctoral Thesis. Academy of Malay Studies, Universiti Malaya, Kuala Lumpur, Malaysia.

Zamri, M. (2014). Innovation T\&L in Malay Language Education. Tanjung Malim, Malaysia: Universiti Pendidikan Sultan Idris (In Malaysia).

Zamri, M. (2016). Sociolinguistics and Language Teaching. Bangi, Malaysia: Faculty of Education Press, Universiti Kebangsaan Malaysia. (In Malaysia). 